Notes on Philonotis (Bartramiaceae, Bryophyta). 17. Australian and New Zealand taxa P. tenuis, P. austrofalcata, P. pseudomollis and P. streimannii, nom. nov.

Koponen, Timo

2020-10

Koponen , T 2020 , ' Notes on Philonotis (Bartramiaceae, Bryophyta). 17. Australian and

New Zealand taxa P. tenuis, P. austrofalcata, P. pseudomollis and P. streimannii, nom. nov.

' , Annales Botanici Fennici, vol. 57 , no. 4-6 , pp. 203-208 . https://doi.org/10.5735/085.057.0402

http://hdl.handle.net/10138/321985

https://doi.org/10.5735/085.057.0402

other

publishedVersion

Downloaded from Helda, University of Helsinki institutional repository.

This is an electronic reprint of the original article.

This reprint may differ from the original in pagination and typographic detail.

Please cite the original version. 


\section{Notes on Philonotis (Bartramiaceae, Bryophyta). 17. Australian and New Zealand Taxa P. tenuis, P. austrofalcata, P. pseudomollis and P. streimannii, nom. nov.}

Author: Koponen, Timo

Source: Annales Botanici Fennici, 57(4-6) : 203-208

Published By: Finnish Zoological and Botanical Publishing Board URL: https://doi.org/10.5735/085.057.0402

BioOne Complete (complete.BioOne.org) is a full-text database of 200 subscribed and open-access titles in the biological, ecological, and environmental sciences published by nonprofit societies, associations, museums, institutions, and presses.

Your use of this PDF, the BioOne Complete website, and all posted and associated content indicates your acceptance of BioOne's Terms of Use, available at www.bioone.org/terms-of-use.

Usage of BioOne Complete content is strictly limited to personal, educational, and non - commercial use. Commercial inquiries or rights and permissions requests should be directed to the individual publisher as copyright holder.

BioOne sees sustainable scholarly publishing as an inherently collaborative enterprise connecting authors, nonprofit publishers, academic institutions, research libraries, and research funders in the common goal of maximizing access to critical research. 


\title{
Notes on Philonotis (Bartramiaceae, Bryophyta). 17. Australian and New Zealand taxa $P$. tenuis, $P$. austrofalcata, $P$. pseudomollis and $P$. streimannii,
} nom. nov.

\author{
Timo Koponen
}

\begin{abstract}
Finnish-Chinese Botanical Foundation, Mailantie 109, FI-08800 Lohja, Finland; and Finnish Museum of Natural History, Botany Unit (Bryology), P.O. Box 7, Fl-00014 University of Helsinki, Finland (e-mail: timo.koponen@helsinki.fi)
\end{abstract}

Received 9 Apr. 2020, final version received 15 Apr. 2020, accepted 20 Apr. 2020

Koponen T. 2020: Notes on Philonotis (Bartramiaceae, Bryophyta). 17. Australian and New Zealand taxa P. tenuis, P. austrofalcata, P. pseudomollis and P. streimannii, nom. nov. - Ann. Bot. Fennici 57: 203-208.

A number of the Australian and New Zealand Philonotis specimens mainly in V.F. Brotherus's herbarium (H-BR) and in NY were studied, with special attention to the placement of mammillae/papillae on the leaf cells and the cell areolation, and to the taxa synonymized previously with Philonotis tenuis. Philonotis austrofalcata (syn. nov. P. rigens) is distinct from $P$. tenuis at the specific level. Bartramia pallida and Philonotis laii are synonymized with Philonotis pseudomollis. Philonotis streimannii T.J. Kop. is a new name for P. fontanoides Broth. \& Watts (hom. illeg.). Lectotypes are selected to P. pallida and P. streimannii. Philonotis pseudomollis is recorded as new to New Zealand.

\section{Introduction}

When the range of Philonotis laii (= P. pseudomollis) was found to extend from SE Asia to the Pacific area (author's unpubl. data), a search through Philonotis taxa described from Australian flora seemed necessary. Streimann and Klazenga (2002) accepted 12 species of Philonotis for Australia and Gilmore (2006) reduced the number to seven. Of them, P. australiensis, P. hastata, P. pyriformis, P. scabrifolia and $P$. slateri were morphologically rather clearly delimited, while $P$. pallida was given as a rare endemic, and the leaves of $P$. tenuis were described as varying "from broadly triangular- lanceolate with a percurrent costa and highly recurved margins to narrowly lanceolate with an excurrent costa and only slightly reflexed margins". Philonotis fontanoides Broth. \& Watts (hom. illeg.) is given as a doubtful name: "This is likely to fall into synonymy with one of the foregoing species".

Gilmore (2006) listed five names as synonyms under Philonotis tenuis: P. fertilis, P. dicranallacea (Watts \& Whitelegge 1906), $P$. austrofalcata (Brotherus \& Watts 1912) and $P$. rigens (Brotherus 1914), and hesitatingly $P$. pseudomollis. Philonotis austrofalcata, $P$. fontanoides, $P$. pallida, $P$. pseudomollis and $P$. rigens are treated in this paper. 


\section{Taxonomy}

\section{Philonotis tenuis s. lato}

A study in V.F. Brotherus's herbarium (H-BR), using the placement of mammillae/papillae on the leaf cells in different combinations and leaf cell areolation as criteria, showed that $P$. tenuis includes different groups. For instance, the type materials of $P$. austrofalcata and $P$. rigens have mid-leaf cells with a central papilla among cells with papilla at the distal cell end in the leaf areolation. This kind of mixture of cells with different papillosity is rare, and until now reported only from $P$. trachyphylla from the Himalayas (Koponen \& Higuchi 2020). The unexpected discovery of $P$. streimannii (P. fontanoides, hom. illeg.) of the section Philonotis in Australia can be cited as an example of the use of mammillae/ papillae as a diagnostic character. All the other species of Philonotis in Australia belong to the section Philonotula.

A preliminary study of Philonotis specimens in $\mathrm{H}-\mathrm{BR}$ and in NY showed that, in addition to the taxa distinguished in this paper from $P$. tenuis s. lato ( $P$. austrofalcata, P. pseudomollis and $P$. rigens), at least two other taxa can be distinguished from $P$. tenuis s. lato on the basis of mammillosity/papillosity in the leaf areolation and the structure of the leaf border. These taxa may merit specific status. However, to confirm this, a revision of $P$. tenuis s. lato including the study of the type specimens, is necessary. I also felt it necessary for another study, not yet published, to try to confirm the characteristics of $P$. tenuis s. stricto.

\section{Philonotis tenuis (Taylor) Reichart s. stricto}

Reise Novara 1(1): 178. 1870. - Bartramia tenuis Taylor, Phytologist 1: 1095. 1844. - TYPE: Australia. Norfolk Island, A. Cunningham (not seen).

The diagnostic characters of $P$. tenuis $s$. stricto based on the protologue (Taylor 1844), Scott and Stone (1976), Streimann (2002), Seppelt (2004), Bednarek-Ochyra (2014) and on a number of Australian and New Zealand specimens studied, are: (1) a rather slender habit with leaves erect-spreading to widely spreading from the stem, and a strongly acuminate or nearly piliferous leaf apex; (2) outer basal cells short-rectangular to subquadrate and mid-leaf cells long-elongate; (3) the cell walls are thick or thin and the papillae at the distal cell end are rather low, leaf cells with central papillae were not observed; (4) The basal leaf margin cells are \pm quadrate or roundish and thin-walled and the margin next to them is biseriate by small, blunt teeth; and (5) the areolation is \pm translucent.

Descriptions and illustrations: Scott and Stone 1976: 339 (pl. 63); Streimann 2002: 8 (fig. 2); Seppelt 2004: 79 (fig. 31); Bednarek-Ochyra 2014: 300 (figs. 1-7).

Total RANGe (Gilmore 2006): Australia, including Lord Howe and Norfolk Islands, New Zealand, Africa.

\section{Philonotis austrofalcata Broth. \& Watts}

Proc. Linn. Soc. New South Wales 37: 373. 1912. Syntypes: Australia. New South Wales: Yarrangobilly Caves, [Reservoir Gully], January 1906 W.W. Watts 8702 (H-BR3121032, marked as "typus!" by Brotherus); syntypes: at ca. $3700 \mathrm{ft}$, 18 January 1906 W.W. Watts 8702 (H-BR 3121038), Yarrangobilly Caves, [Reservoir Gully], at ca. 3800 ft., 18 January 1906 W.W. Watts 8680 (H-BR3121054), W.W. Watts 8718 (H-BR3121004); [Gully beyond Kiandra Road], January 1906 W.W. Watts 8854, forma (H-BR3121006, marked "typus!", by Brotherus), at ca. $4000 \mathrm{ft} ., 22$ January 1906 W.W. Watts 8854 (H-BR-3121057).

Philonotis rigens Broth., Pap. \& Proc. Royal Soc. Tasmania 1913: 195. 1914, syn. nov. - Holotype: From the protologue: "Near Sorell"; from the label: "V. F. B. Bartramia (Philonotis) rigens Broth. $+P h$. tenuis cfr. The Bridge Gully, Glen Rae, Wattle Hill, Sorell! 9 January 1891 W.A. Weymouth 556, R.Br 11/9/91" (H-BR3121052)

Brotherus and Watts (1912) gave only two collector numbers of $P$. austrofalcata with localities $(8702,8854)$. In addition, they mentioned two other localities without citing the collector numbers: "near Hot Springs; Cliffs, Yarrangobilly Village". Based on the locality information, the following specimens are obviously syntypes: Yarrangobilly, near Hot Springs at ca. $3200 \mathrm{ft} ., 18$ January 1906 W.W. Watts 8577 (H-BR3121037); Gully, at ca. $3800 \mathrm{ft}$., 20 January 1906 W.W. Watts 8790 (H-BR3121048); Falls, at ca. 4000 ft., 22 
January 1906 W.W. Watts 8799 (H-BR3121045), 8804 (H-BR3121050), 8846 ex $p$. (H-BR3121023), 8856 (H-BR3121056).

The collector of the type specimen of $P$. rigens has been unknown (Gilmore 2006). Rodway (1913) says that W.A. Weymouth submitted his large collections to European experts: the hepatics to Stephani, the Sphagna to Warnstoft [sic!], Othotricha to Venturi, and the rest to V.F. Brotherus. V. F. B. in the upper left corner of the specimen means that so happened. V.F. Brotherus received a total 46 letters in 18921927 from W.A. Weymouth (Koponen \& Piippo 2002). The marking "R.Br.11/9/91" is added later on the specimen and possibly means that Weymouth showed or gave a duplicate of the specimen to Mr. R. Brown.

The syntype specimens of $P$. austrofalcata differ in several characters from the circumscription of P. tenuis s. stricto. Philonotis austrofalcata has brown, imbricate, falcate and concave leaves with a strong costa, (up to $40 \mu \mathrm{m}$ wide at insertion), and percurrent to shortly excurrent at the acute apex. In some specimens the apex is very short, nearly obtuse. The leaf cells are thinwalled and from nearly quadrate to short rectangular at mid-leaf. The leaf cells of the basal leaf are nearly smooth or with bulging cell ends. The mid-leaf cells have a papilla at the distal cell end, on the lumen at the distal or proximal cell end, or the cells have a central papilla. In some specimens cells with a central papilla are frequent. The leaf margin is biseriate at mid-leaf.

The type of $P$. rigens has similar imbricate, falcate and acute leaves with excurrent costa as $P$. austrofalcata. The former is darker, the cell walls are thicker and the costa stronger (up to $50 \mu \mathrm{m}$ wide at insertion). The mammillosity/ papillosity is similar as in $P$. austrofalcata, but the papillae tend to be taller. The leaf margin at mid-leaf is biseriate. Philonotis rigens is synonymized with $P$. austrofalcata.

Additional specimens eXAmined. Australia. New South Wales: Cuttings, Mt. Talbigo, at ca. 2500 m, January 1906 W.W. Watts 8480 (H-BR3121051). Victoria: Lorne, Erskine River, November 1919 W.W. Watts 1029, as P. fontanoides (H-BR3121046), W.W. Watts 1053a, as P. austrofalcata (H-BR3121055), W.W. Watts 1057, as P. austrofalcata (H-BR3121047).

\section{Philonotis pseudomollis (Müll. Hal.)}

\section{A. Jaeg.}

Ber. Thätigk. St. Gallischen Naturwiss. Ges. 1873-74: 1875 (Ad. 1: 544). 1875. - Bartramia pseudomollis Müll. Hal., Linnaea 37: 150. 1872. — TYPE: Australia. Queensland, Brisbane river Australiae occidentalis, unde inter alios muscos misit Amalie Dietrich (not seen).

Bartramia pallida Hampe, Linnaea 40: 307. 1876, syn. nov. - Philonotis pallida (Hampe) A. Jaeg., Ber. Thätigk. St. Gallischen Naturwiss. Ges. 1877-78: 1879 (Ad. 2: 701). 1879. - Lectotype (designated here): Australia. "Ostaustralien", leg. Eaves (H-BR3121012).

Philonotis laii T.J. Kop., Acta Bryolich. Asiatica 3: 91, fig. 1. 2010, syn. nov. - Holotype: China. Hunan Prov., Wulingyuan World Heritage Area, Zhangjiajie, Huangshizhai. On cliffs in low evergreen forest along path, on moist partially shaded cliff, at 910-985 m a.s.1., 8 October 1997 T. Koponen, S. Huttunen \& P.-C. Rao 51641 (H). Synonyms and paratypes, see Koponen (2010).

The diagnostic characters of $P$. laii given by Koponen $(2010,2019 a, 2019 b)$ are very narrow, elongate leaves with an acuminate apex and a percurrent costa. The mid-leaf cells near costa are up to $50 \mu \mathrm{m}$ long but narrow, ca. $5 \mu \mathrm{m}$ broad. The leaf cell areolation is translucent. A special character is that at the end of the growing season, the stems and innovations may grow to slender stolons with numerous propagules.

The description of $P$. pseudomollis (Müller 1872) and especially of the leaf cells: "cellulis pellucidis minutis angustis elongatis" and his note: "Ex habitu B. mollis Javanicae haud dissimilis" agree with the characters of $P$. laii.

Hampe's (1876) protologue of Bartramia pallida includes a description of sterile shoots: "ramis sterilibus gracillimis elongatis uncialibus plumulosis pallidis laxe foliates"; leaf cells: "cellulis parvis rectangulis subpellucida" and evident propagules: "nodulis interruptis evidenter tuberculate". These characters also fit $P$. laii, as well as Hampe's note: "Inter Bartramias plumulosas colore pallido notabilis".

Gilmore's (2006) note on P. pallida: "Few cells are found between the costa and the margin as the leaves are quite narrow. The leaf apices are also rather narrow but somewhat rounded" is accurate. This character was confirmed by studying the type (see above). My study in V.F. Brotherus's herbarium revealed several more Australian specimens. 
Philonotis pseudomollis was listed hesitatingly as a synonym of $P$. tenuis by Dixon (1942) and Gilmore (2006). Cairns et al. (2019) considered P. pseudomollis to be an uncertain taxon, pending a detailed study. Brotherus (1924: 463) may have had an idea of its status, while he gave $P$. pseudomollis, $P$. slateri and $P$. tenuis as separate species. It may be worth mentioning that the sheet of $P$. pseudomollis originating from W. Mitten's herbarium (NY) bears a handwritten copy of the description of P. pseudomollis, a correctly identified specimen, Bailey 254 (see below) and a sketch of a long and narrow leaf with acuminate apex.

DesCriptions AND ILluStrations: Tixier 1986: 229, (fig. 2, as Philonotis angustissima); Whittier 1976: 189 (fig. 52H-K, as P. runcinata); Tan and Ho 2008: (fig. 9 and figs. on pp. 78 and 79, as P. hastata); Koponen 2010: 138 (fig. 1, as P. laii); Koponen et al. 2019: 81 (fig. 4, as P. laii).

Total Range. Philonotis pseudomollis (old records as $P$. laii) has a wide range in continental SE Asia (map in Koponen 2010), in Hunan province of China (Koponen 2019a), and it has been recorded from Japan and the Philippines (Koponen 2018), New Guinea (Koponen 2019b), Vietnam (Koponen et al. 2019), Pakistan (Koponen \& Higuchi 2020). It has a wide range also in the Pacific from Hawai'i to New Caledonia (author's unpubl. data).

The stolon-like shoots in the New Zealand specimen cited below are in the beginning of their growth. At the leaf base there are only few cells between the leaf margin and costa and the mid-leaf cells are long, rectangular and narrow. This fits with $P$. pseudomollis, and the specific character of $P$. pseudomollis, the abundant propagules along the stolon confirms the identity.

Selected specimens examined. Australia. "Ostaustralien”. Mt. William, leg. Sullivan (H-BR3121026). Queensland: Brisbane, (J.B.) Bailey 254 (NY, herb. W. Mitten). New South Wales: Richmond R., Rouo Falls, 29 September 1900 W.W. Watts 4841 (H-BR3121053, as P. percapillaris Müll. Hall., nom. nud.), September 1900 W.W. Watts a.m.s (NY, det. Brotherus as P. percapillaris); Richmond River, Uralba, September 1901 W.W. Watts a.m.8 (NY, det. as $P$. tenuicola Geh. by Brotherus); Richmond River, Alstonville Cutting, September 1902 W.W. Watts 5730, with propagules (H-BR3121043, as P. micropteris Broth., nom. nud.); Alstonville Road, 27 September 1896 W.W. Watts 886 (NY, det. Brotherus as P. slateri); National Park, 22 July $1899 \mathrm{~W}$.
Forsyth 595 (H-BR3121018). New Zealand (first record). Canterbury: Banks Peninsula, Hickory Bay, 6 June 1983 A.J. Fife 5622, as P. tenuis (NY, ex CHR 103669).

Philonotis streimannii T.J. Kop., nom. nov. (Fig. 1)

Philonotis fontanoides Broth. \& Watts, Proc. Linn. Soc. New South Wales 37: 374. 1912, hom. illeg. - Lectotype (designated here): Australia. New South Wales, Yarrangobilly, swamp, Kiandra Road about $48 \mathrm{~m}$. from Tumut, 4-5000 ft., 24 January 1906 W.W. Watts 8879 (H-BR3121039). SyNTYPES: The same date and site, identical with the lectotype, “W.W. Watts 8873" (H-BR3121030), “W.W. Watts $8879+$ 8873" (H-BR3121003).

Eтymology: I selected the epithet streimannii to honor the memory of the Estonian bryologist, Heinar Streimann (1938-2001), an expert of Australian bryoflora, and the most notable collector and distributor of bryophytes from Papua New Guinea.

Description BASED ON SYNTYPE H-BR3121003. Plants brownish, loosely tufted, shoots to $3 \mathrm{~cm}$, innovations \pm erect; leaves to $2.2 \mathrm{~mm}$ long and $0.7-1.0 \mathrm{~mm}$ broad, not arranged in rows; leaf bases erect when dry covering the stem, leaves falcate-secund, broadest above insertion, slightly plicate, from ovate base gradually tapering to acuminate apex; margin plane, several basal marginal cells thin-walled, entire, margin cells next to them and at mid-leaf double-crenulate, at apex serrate; costa very strong, $100-125 \mu \mathrm{m}$ broad at leaf insertion, dorsal side smooth at base, slightly mammillate by protruding cell corners apically, excurrent; leaf areolation \pm translucent, all leaf cells thin-walled; basal leaf cells rectangular or rhomboidal, mammillate at proximal cell end, $12-25 \times 60-90 \mu \mathrm{m}$, at mid-leaf cells papillate at proximal cell end, $12-20 \times 37-55 \mu \mathrm{m}$, gradually narrower toward apex, at apex papillate at proximal cell end, cells 5-12 × 20-55 $\mu \mathrm{m}$. Dioicous. Female plant and sporophyte not seen; base of perigonial leaves erect and concave, leaves from very broad lower part quickly tapering to spreading, secund apex with excurrent costa; leaf cells in ovate part thin-walled, slightly mammillate at proximal cell end, $12-25 \times 50-112 \mu \mathrm{m}$, in narrow apical part cells thick-walled, ca. $5 \mu \mathrm{m}$ broad; leaf margin in ovate part entire, cells narrow, elongate, apical leaf margin double-crenulate or serrate.

Gilmore (2006) regarded P. fontanoides as a doubtful species. Brotherus (1924) accepted 


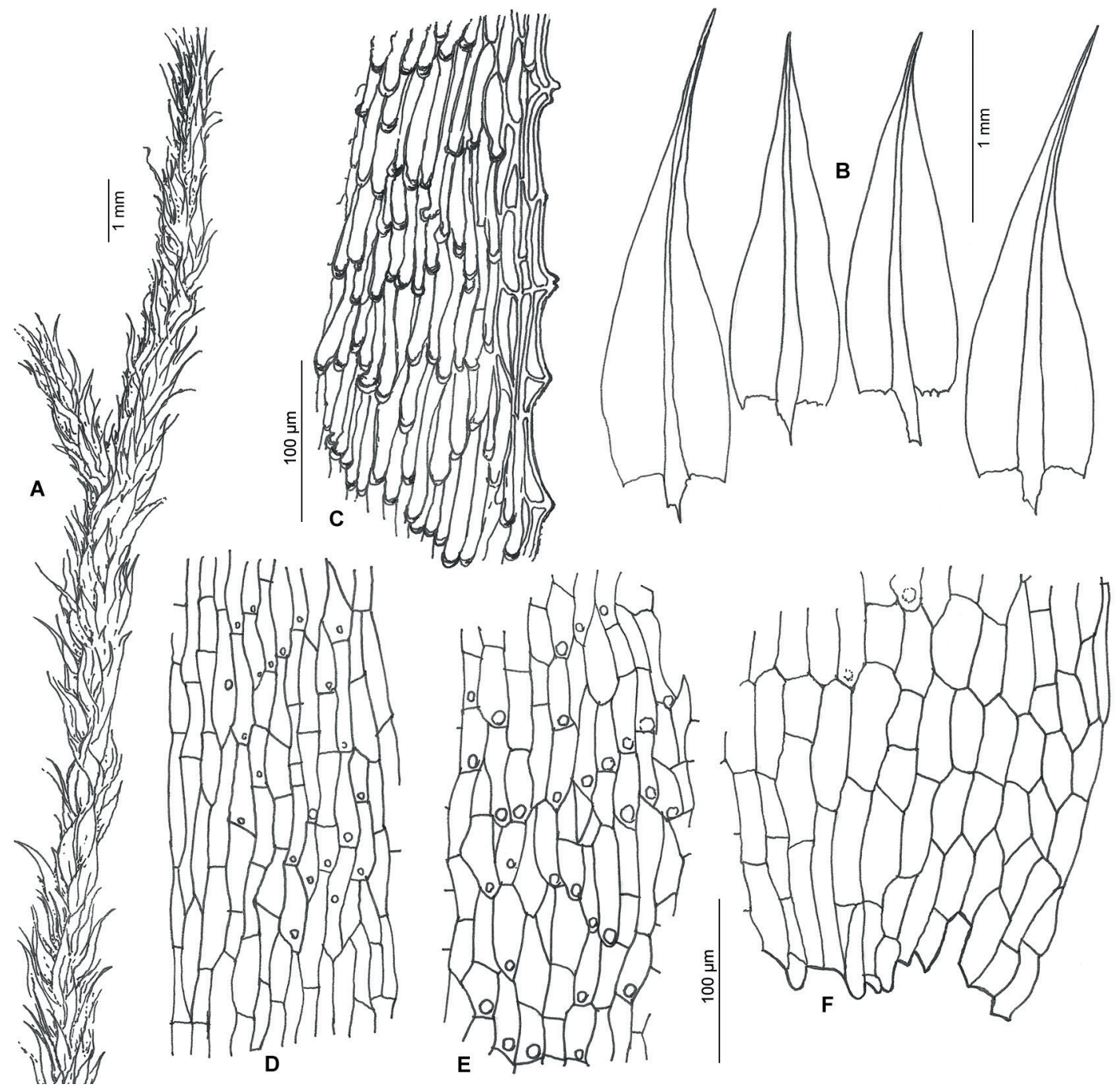

Fig. 1. Philonotis streimannii (from H-BR3121033). - A: Habit. - B: Leaves. - C: Leaf border near leaf apex. - D: Areolation at mid-leaf. - E: Areolation at basal part of leaf. - F: Areolation and leaf margin at leaf insertion.

it in the section "Euphilonotis" in the group with $P$. falcata, P. afrofontana and P. austrofalcata having, among other common characters, "mamillös vortretenden Zellecken, und zwar auf Aussenseite meist die unteren Zellecke, auf der Innenseite die obere Zellecke vorgewölbt".

The sectional characters separating the section Philonotis from the section Philonotula (see Koponen et al. 2012) are the major mammilla/ papilla at the proximal cell end of all leaf cells and the double-crenulate leaf margin at midleaf. The exceptions of this mammilla/papilla arrangement are P. yezoana, with central papillae on the mid-leaves, and P. trachyphylla having cells with central papillae and cells with papillae at the proximal cell end (Koponen \& Higuchi 2020).

Philonotis fontanoides has the major mammilla/papilla at the proximal cell end of all leaf cells and the double-crenulate leaf margin at mid-leaf, and, accordingly, it belongs in the section Philonotis. Since P. fontanoides is a later homonym, a new name $P$. streimannii is proposed for it. It is easily distinguished from the other Australian Philonotis by the sectional characters mentioned above. The leaf shape, 
leaf cell areolation and strong costa separate $P$. streimannii from $P$. fontana (see its description in Koponen et al. 2012).

Most of the taxa of the section Philonotis occur on the northern hemisphere (see Koponen et al. 2012). Philonotis tricolor is known from central African high mountains (Koponen 2015) and $P$. brevifolia from Chile (Jimenez et al. 2016). The most widely ranging southern hemisphere taxon of the section Philonotis is circumsubantarctic P. polymorpha (Ochyra et al. 2008). Total RANGe. Endemic to Australia.

\section{Acknowledgements}

I thank the Curator in NY for forwarding Mitten's specimen on loan and two reviewers for their valuable comments on the manuscript.

\section{References}

Bednarek-Ochyra H. 2014: Taxonomic status of two subantarctic species of Philonotis (Bartramiaceae, Musci). Cryptogamie, Bryologie 35: 387-395.

Brotherus V.F. 1924: Musci (Laubmoose). II. Spezieller Teil. — In: Engler A. \& Prantl K. (ed.), Die natürlichen Pflanzenfamilien nebst ihren Gattungen und wichtigeren Arten insbesondere den Nutzpflanzen, 2. Aufl. 10(1): 129-131, 143-478.

Brotherus V.F. \& Watts W.W. 1912: The mosses of the Yarrangobilly Caves district, N.S.W. - Proceedings of the Linnean Society of New South Wales 37: 363-382.

Cairns A., Meagher D. \& Ramsay H. 2019: A revised checklist of the moss flora of the Australian Wet Tropics. Telopea 22: 1-30.

Dixon H.N. 1942: Additions to the mosses of North Queensland. - Proceedings of the Royal Society of Queensland 53: 23-40.

Gilmore S.R. 2006: Bartramiaceae. - In: McCarthy P.M. (ed.), Flora of Australia, vol. 51. Mosses 1: 248-270. ABRS Canberra \& CSIRO Publishing, Melbourne.

Hampe E. 1876: Musci novi Musci Melbournei. Continuatia. — Linnaea 40: 301-326.

Jimenez S., Suárez G. \& Larraín J. 2016: Rediscovery and lectotypification of Philonotis brevifolia Herzog (Bartramiaceae, Bryophyta), a neglected species from Chile. - Cryptogamie, Bryologie 37: 113-118.

Koponen T. 2010: Bryophyte flora of the Hunan Province, China. 14. Philonotis laii, species nova (Bartramiaceae, Musci). - Acta Bryolichenologica Asiatica 3: 137-143.

Koponen T. 2015: Notes on Philonotis (Bartramiaceae, Musci). 15. Philonotis on Mt. Kilimanjaro, Tanzania. Arctoa 24: 382-388.
Koponen T. 2018: New national and regional bryophyte records, 56. 31. Philonotis laii T.J. Kop. - Journal of Bryology 40: 285.

Koponen T. 2019a: Bryophyte flora of Hunan Province, China 26. Bartramiaceae Bryophyta). - Acta Bryolichenologica Asiatica 8: 85-103.

Koponen T. 2019b: Bryophyte flora of the Huon Peninsula, Papua New Guinea. LXXVIII. New Guinea Philonotis (Musci, Bartramiaceae) revisited; collections made by B.O. van Zanten in 1968. - Acta Bryolichenologica Asiatica 8: 9-24.

Koponen T. \& Higuchi M. 2020: Revision and checklist of Philonotis (Bartramiaceae, Bryophyta) in Pakistan, with the status of P. trachyphylla Dixon \& Badhw. and note on Mnium riparium Mitt. (Mniaceae). - Bulletin of the National Science Museum, Tokyo B 46(2): 1-10.

Koponen T., Ignatova E.A., Kuznetsova O.I. \& Ignatov M.S. 2012: Philonotis (Bartramiaceae, Musci) in Russia. Arctoa 21: 21-62.

Koponen T., Nguyen T.L., Luong T.T. \& Huttunen S. 2019: Revision and checklist of the moss families Bartramiaceae and Mniaceae (Bryophyta) in Vietnam. - Hattoria 10: 69-107.

Koponen T. \& Piippo S. 2002: Viktor Ferdinand Brotherus and his collection of letters. - Bryobrotherella 5: 1-29.

Müller C. 1872: Musci Australici praesertium Brisbanici novi. - Linnaea 37: 143-162.

Ochyra R., Lewis Smith R.I. \& Bednarek-Ochyra H. 2008: The illustrated moss flora of Antarctica. - Cambridge University Press.

Rodway L. 1913: Tasmanian bryophytes, Part I. — Papers \& Proceedings of the Royal Society of Tasmania 1912: 3-24.

Rodway L. 1914: Tasmanian bryophytes, Part III. - Papers \& Proceedings of the Royal Society of Tasmania 1913: 177-263.

Scott A.M. \& Stone I.G. 1976: The mosses of southern Australia. - Academic Press, London, New York, San Francisco.

Seppelt R.D. 2004: The moss flora of Marquarie Island. Australian Antarctic Division, Kingston.

Streimann H. 2002: The mosses of Norfolk Island. - Flora of Australia Supplementary Series 16, Australian Biological Resources Study, Canberra.

Streimann H. \& Klazenga N. 2002: Catalogue of Australian mosses. - Flora of Australia Supplementary Series 17, Australian Biological Resources Study, Canberra.

Tan B.C. \& Ho B.C. 2008: A guide to the mosses of Singapore. - Science Centre, Singapore.

Taylor T. 1844: Descriptions of new mosses and lichens from the Australian colonies. - Phytologist 1: 1093-1096.

Tixier P. 1986: Bryophyta exotica, VIII. Bryophytes de Nouvelle-Caledonie. - Cryptogamie Bryologie et Lichénologie 7: 225-234.

Watts W.W. \& Whitelegge H.L.K. 1906: Census muscorum Australiensium. - Proceedings of the Linnean Society of New South Wales 30, Supplement: 1-90.

Whittier H.O. 1976: Mosses of the Society Islands. - The University Presses of Florida, Gainesville. 